\title{
Translation, Adaptation and Validation of the "Cultural and Psychosocial Influences on Disability (CUPID) Questionnaire" for Use in Brazil
}

\author{
Andrea Lepos Ferrari ${ }^{1}$ \\ Patricia Campos Pavan Baptista ${ }^{2}$ \\ Vanda Elisa Andres Felli ${ }^{3}$ \\ David Coggon 4
}

The paper describes the adaptation and testing of the Cultural and Psychosocial Influences on Disability Questionnaire for use in Portuguese. The cross-cultural adaptation followed the steps of translation, back-translation, evaluation of the translations by a committee of judges, and then piloting of the pre-final version. This was performed in a sample of 40 nursing staff from the Hospital at the University of São Paulo. Adjustments were made after review of the translations by the committee of judges (CVI $\leq 80 \%$ ). The pilot study was used to test whether questions could be satisfactorily understood and completed ( $\geq$ $85 \%$ of subjects). The Brazilian version of the Questionnaire is an adequate instrument for the ascertainment of occupational activities, psychosocial aspects of work, musculoskeletal symptoms and associated disabilities in nursing staff.

Descriptors: Translations; Validation Studies; Occupational Health; Cumulative Trauma Disorders.

\footnotetext{
${ }^{1}$ RN, Master's Student, Escola de Enfermagem, Universidade de São Paulo, SP, Brazil. E-mail: dealepos@usp.br.

${ }^{2}$ RN, Ph.D. in Nursing, Professor, Escola de Enfermagem, Universidade de São Paulo, SP, Brazil. E-mail: pavanpati@usp.br.

${ }^{3}$ RN, Ph.D. in Nursing, Associate Professor, Escola de Enfermagem, Universidade de São Paulo, SP, Brazil. E-mail: vandaeli@usp.br.

${ }^{4}$ Ph.D., Professor, Occupational and Environmental Health, Southampton University, UK. E-mail: dnmc@mrc.soton.ac.uk.
} 


\title{
Tradução, adaptação e validação do Cultural and Psychosocial Influences on Disability (CUPID) Questionnaire para uso no Brasil
}

O objetivo deste estudo foi descrever a adaptação e validação do Questionário Pesquisa Internacional sobre as Influências Físicas, Culturais e Psicossociais nos Sintomas Musculoesqueléticos e Incapacidades Associadas, para a língua portuguesa. O processo de adaptação transcultural seguiu as etapas de tradução, retrotradução, avaliação das traduções por um comitê de juízes e, em seguida, teste da versão pré-final. Utilizouse amostra de 40 trabalhadores de enfermagem do Hospital da Universidade de São Paulo. Adaptações foram feitas após a submissão ao comitê de juízes (IVC $\leq 80 \%$ ). O teste piloto testou a compreensão das questões pelo seu preenchimento ( $\geq 85 \%$ dos sujeitos). A versão brasileira do Questionário mostrou ser instrumento adequado para a verificação das atividades profissionais, aspectos psicossociais do trabalho e sintomas osteomusculares, associados à incapacidade entre os trabalhadores de enfermagem.

Descritores: Tradução (produto); Estudos de Validação; Saúde do Trabalhador; Transtornos Traumáticos Cumulativos.

\section{Traducción, adaptación y validación del cuestionario Cultural and Psychosocial Influences on Disability (CUPID) para uso en Brasil}

\begin{abstract}
El objetivo de este estudio fue describir la adaptación y validación del cuestionario Investigación Internacional sobre las Influencias Físicas, Culturales y Psicosociales en los Síntomas Musculares Esqueléticos e Incapacidades Asociadas, para la lengua portuguesa. El proceso de adaptación transcultural siguió las etapas de traducción, retrotraducción, evaluación de las traducciones por un comité de jueces y, en seguida, la realización de una prueba de la versión prefinal. Se utilizó una muestra de 40 trabajadores de enfermería del Hospital de la Universidad de Sao Paulo. Las adaptaciones fueron hechas después de someterlo al comité de jueces (IVC $\leq 80 \%$ ). La prueba piloto comprobó la comprensión de las preguntas a través del llenado ( $\geq 85 \%$ de los sujetos). La versión brasileña del cuestionario mostró ser un instrumento adecuado para la verificación de las actividades profesionales, aspectos psicosociales del trabajo y síntomas osteomusculares, asociados a incapacidad entre los trabajadores de enfermería.
\end{abstract}

Descriptores: Traducción (producto); Estudios de Validación; Salud Laboral; Trastornos de Traumas Acumulados.

\section{Background}

Work-Related Musculoskeletal Disorders (WRMD) are an important cause of morbidity and disability in industrialized countries, with major economic impact ${ }^{(1-4)}$. Their management and prevention requires careful evaluation of workers' occupational activities and work conditions, including both technical and organizational aspects of work $^{(5-6)}$.
Accordingly, Brazilian researchers have adapted various established instruments for the assessment of musculoskeletal problems in workers, including the Nordic Questionnaire(7), the Disabilities of the Arm, Shoulder and Hand (DASH) Questionnaire(8) and the Oswestry Disability Index ${ }^{(9)}$. However, most of these questionnaires focus on specific anatomical regions, and 
do not cover the nature of work and the work conditions that might be associated with symptoms. The "Cultural and Psychosocial Influences on Disability (CUPID)

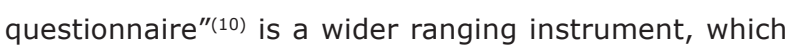
ascertains demographic characteristics, a range of occupational physical activities, psychosocial aspects of work, musculoskeletal symptoms at multiple anatomical sites, associated disability for common everyday tasks, mental health, tendency to worry about common (nonmusculoskeletal) somatic symptoms, and also beliefs about the nature and severity of WRMD(11).

The theoretical approach of the conception of the Questionnaire is based on the hypothesis that workrelated musculoskeletal symptoms and resultant disability are influenced by cultural beliefs and expectations, as well as by physical activities and mental health"(10-11).

The CUPID questionnaire(10) is in two parts: a baseline questionnaire, which can be used to collect data about workers in cross-sectional surveys, and a shorter follow-up questionnaire, which assesses the course and impact of symptoms at later follow-up.

The CUPID questionnaire is currently being used in an international multi-center study - "Cross-cultural Study of Musculoskeletal and Other Somatic Symptoms and Associated Disability", with financial support from the Colt Foundation, aimed at comparing the prevalence of musculoskeletal symptoms and disability in workers carrying out similar physical activities in a variety of cultural settings. Brazil is taking part in this CUPID project with 21 other countries. As a prelude to data collection, it was necessary to translate the CUPID questionnaire into Brazilian Portuguese, and then check its validity and applicability by independent back-translation to English, and by piloting in a sample of Brazilian workers.

The importance of adapting the questionnaire for the Brazilian culture is guided by comprehensive and accurate diagnoses, which permit appropriate and effective proposals of preventive strategies to avoid work-related musculoskeletal symptoms and their resultant disability. Also, international data comparison highlights the influences of different cultures on the manifestation of the work-related musculoskeletal symptoms and disabilities. Therefore, England, Australia, Italy, England, New Zealand, Greece, South Africa and Brazil ${ }^{(12-13)}$ are conducting studies with nursing workers in this project. So, with a view to testing the capacity of the instrument to identify musculoskeletal symptoms and its relationships in different countries and cultures, a multi-center international was proposed, and Brazil is taking part in the CUPID Project with other 21 countries.

The cultural adaptation of the CUPID differs from other studies of the same type which propose to investigate the psychometric properties of the questionnaires, because they were designed as a Likert scale(14-17). CUPID is an instrument whose answers mostly offer a qualitative perspective. On the other hand, the questionnaire is very extensive, which makes it difficult to immediately apply other possible techniques for content validation. Therefore, this publication intends to contribute to the understanding of the cultural adaptation of this type of instrument on workers' health, showing the steps followed for this purpose in detail.

\section{Purpose}

The purpose was to evaluate a translation of the CUPID questionnaire into the Portuguese language spoken in Brazil, checking the accuracy of the translation, its content validity, and whether it could be clearly understood when piloted in a sample of nursing staff.

\section{Method}

The study is characterized as methodological(18). The title of the CUPID Questionnaire in Portuguese is "Pesquisa Internacional sobre as Influências Físicas, Culturais e Psicossociais nos Sintomas Musculoesqueléticos e Incapacidades Associadas".

\section{Procedures for adaptation}

An adaptation of the CUPID questionnaire was performed, following the steps that are internationally recommended for translation, back-translation, evaluation of the translations by a judging committee, and then pilot testing of the pre-final version(18-20).

\section{Forward translation}

The CUPID questionnaire was translated from the original language - English - into the Portuguese language spoken in Brazil, by a bilingual native translator. After the translation, the translator and the lead researcher made a summary of the adjustments in this phase. The translated questionnaire was sent to the general coordinator of the project and its author, who did not indicate any further adjustments. 


\section{Back-translation}

Independent back-translation to English was carried out by an American bilingual translator, whose mother tongue was English as spoken in the United States. This version was evaluated and compared to the original in English to identify discrepancies. The questionnaire was then re-submitted to the general coordinator of the project, who suggested adjustments that would maintain the same meaning as the original idiom - English spoken in the United Kingdom.

\section{Judging committee}

The translated and back-translated versions of the questionnaire were submitted to a judging committee of specialists in its subject matter. This judging committee comprised orthopedists, medical doctors, physiotherapists, nurses and occupational therapists. They evaluated the translations and amendments were made to produce a pre-final version of the questionnaire. As part of this process, the content validity of questions was checked. A content validity index (CVI) was derived for each item of the questionnaire, indicating the percentage of agreement between the specialists, with an $0.80 \mathrm{CVI}$ pre-set as the level that would be regarded acceptable. After the necessary adjustments, the prefinal version of the questionnaire was re-submitted to the general coordinator of the project, who made further adjustments ${ }^{(20)}$.

The pre-final version of the CUPID questionnaire was then tested in a pilot study.

\section{Pilot testing}

The objective of the pilot study was to establish whether the questionnaire could be satisfactorily understood and completed by people from the target population. The possibility of adjustments was considered if $15 \%$ or more of participants had difficulty in comprehending or answering an instrument item ${ }^{(21)}$.

\section{Setting and subjects}

The study took place at the University Hospital of the University of São Paulo (HU-USP) - Nursing Department. Subjects were forty (40) nursing staff, including nurses, nursing technicians and nursing auxiliaries. The inclusion criteria were: age between 20 and 59 years, and employment in the Department for at least 12 months at the time of data collection. Workers who were absent or on vacation were excluded, as were nurses who were engaged in administrative activities only. The study sample comprised 11 nurses (26\%), 16 nursing technicians (41\%), and 13 nursing auxiliaries $(33 \%)$ from several units and shifts.

\section{Data collection}

Data collection was carried out during July and August 2008. The study sample was identified from a list of all nursing workers in the Nursing Department, with the names of the forty (40) subjects being randomly selected. The lead researcher contacted these individuals when they were at work; and explained the project and its objectives. After consent had been obtained, the researcher gave participants a copy of the pre-final version of the CUPID questionnaire to complete, and asked that it be returned at the end of their work shift. Participants were instructed that, if they experienced difficulty in understanding or answering a question, they should leave it blank, thus permitting a check on the need to adjust the instrument.

\section{Analysis}

The data collected were entered into an electronic spreadsheet $\left(\right.$ Excel $^{\circledR}$, version 2007), and analyzed using simple descriptive statistics. The main focus was on questionnaire items that had not been satisfactorily answered. The study received the approval from the National Council for Research Ethics (CONEP/MS), and from the Ethics and Research Committee of HU-USP. All participants signed the Free and Informed Consent Term

\section{Results}

\section{Adaptation of the CUPID Questionnaire}

As already described, the adaptation of the CUPID Questionnaire was carried out in a series of stages, comprising translation, back-translation, evaluation by a judging committee, and piloting of the pre-final version.

\section{Translation}

During the translation, it was a necessary to adapt some terms in order to maintain the same meaning as the original (Figure 1). 


\begin{tabular}{|l|l|l|l|l|}
\hline \multicolumn{1}{|c|}{$\begin{array}{c}\text { Questionnaire and } \\
\text { question }\end{array}$} & \multicolumn{1}{|c|}{ Original Version (English) } & \multicolumn{1}{|c|}{$\begin{array}{c}\text { Translated Version } \\
\text { (Portuguese) }\end{array}$} & $\begin{array}{c}\text { Adjustments to } \\
\text { Portuguese }\end{array}$ & $\begin{array}{c}\text { Reasons (Brazilian } \\
\text { context) }\end{array}$ \\
\hline BQ-Question 4 & $\begin{array}{l}\text { White British, Bangladeshi, } \\
\text { Indian, Pakistani, Black African/ } \\
\text { Caribbean, Chinese }\end{array}$ & $\begin{array}{l}\text { Branca Britânica, } \\
\text { Paquistanesa, Bengalesa, } \\
\text { Negra Africana/Caribenha, } \\
\text { Indiana, Chinesa }\end{array}$ & $\begin{array}{l}\text { Branco, Preto, Amarelo, } \\
\text { Indígena, Pardo }\end{array}$ & $\begin{array}{l}\text { Classification used for } \\
\text { races }\end{array}$ \\
\hline BQ-Question 5 & Full time education & Educação de tempo integral & Educação fundamental & $\begin{array}{l}\text { Equivalent term to the } \\
\text { level of education }\end{array}$ \\
\hline BQ-Question 6 & Centimeters or feet & Centímetros ou pés & Centímetros & Unit of height measure \\
\hline BQ-Question 11 & 30 flights of stairs a day & 30 lances de escada por dia & $\begin{array}{l}30 \text { degraus de escada } \\
\text { por dia }\end{array}$ & $\begin{array}{l}\text { Appropriateness to the } \\
\text { context }\end{array}$ \\
\hline $\begin{array}{l}\text { BQ-Questions 17, 18, } \\
\text { 19, 20, 21, 42, 47, 51 }\end{array}$ & Low back pain & Dor na baixa lombar & Lombalgia & Normal; usage \\
\hline BQ-Question 48 & $\begin{array}{l}\text { RSI (repetitive strain injury), } \\
\text { WRULD (work related upper } \\
\text { limb disorder, CTS (cumulative } \\
\text { trauma syndrome) }\end{array}$ & $\begin{array}{l}\text { LER (lesão por esforços } \\
\text { repetitivos), DORT } \\
\text { (distúrbio osteomuscular } \\
\text { relacionado ao trabalho) }\end{array}$ & Normal usage \\
\hline $\begin{array}{l}\text { FQ-Questions 4, 5, 6, } \\
7,25\end{array}$ & Low back pain & Dor na baixa lombar & Lombalgia & Normal usage \\
\hline
\end{tabular}

Figure 1 - Summary of adjustments made during translation in the Baseline Questionnaire (BQ) and in the Follow-up Questionnaire (FQ)

\section{Back-translation}

During back-translation of the CUPID questionnaire, no items were encountered that required alteration. The questions maintained the meaning of the original version. The lead researcher checked for words and phrases that might imply a divergence of meaning, comparing the back-translated version to the original and, where there was doubt, discussed the problem with the translator.

\section{Judging Committee}

After the Judging Committee's evaluation, the
CUPID questionnaire underwent further adjustments, according to the specialists' guidance, where the Content Validity Index (CVI) was lower than $0.80^{(18)}$. It was deemed unnecessary to return the responses to the judges, as the CVI was lower than 0.80 for only 3 items, with satisfactory agreement for the other 73 questions. The problems the specialists identified that led to alterations are described in Figure 2.

The further adjustments that were then made by the general coordinator are set out in Figure 3.

\begin{tabular}{|l|l|l|l|c|}
\hline \multicolumn{1}{|c|}{ Questionnaire and item } & \multicolumn{1}{|c|}{$\begin{array}{c}\text { Back-translated } \\
\text { version }\end{array}$} & $\begin{array}{c}\text { Adjustment to } \\
\text { Portuguese }\end{array}$ & \multicolumn{1}{c|}{ Reasons } & CVI \\
\hline BQ-Question 11c & Esticamento & Extensão & Proper definition of the movement made & 0.66 \\
\hline BQ-Question 11 e & Somente & Exclusão do termo & unnecessary word to say the same, understanding & 0.66 \\
\hline $\begin{array}{l}\text { BQ-Questions 17, 18, 19, 20, } \\
21,42,47,51\end{array}$ & Lombalgia & Dor lombar & technical term & 0.50 \\
\hline FQ-Questions 4, 5, 6, 7, 25 & Lombalgia & Dor lombar & technical term & 0.50 \\
\hline
\end{tabular}

Figure 2 - Summary of adjustments made during the judging committee stage in the Baseline Questionnaire (BQ) and in the Follow-up Questionnaire (FQ)

\begin{tabular}{|c|c|c|c|c|c|}
\hline $\begin{array}{l}\text { Questionnaire and } \\
\text { Item }\end{array}$ & $\begin{array}{l}\text { Translated Version } \\
\text { (Portuguese) }\end{array}$ & Back-translation & Adjustments & $\begin{array}{l}\text { Final Portuguese } \\
\text { version }\end{array}$ & Reasons \\
\hline BQ-Question 7a & $\begin{array}{l}\text { "... ao menos uma vez } \\
\text { por dia" }\end{array}$ & $\begin{array}{l}\text { "...less than one time } \\
\text { per day" }\end{array}$ & $\begin{array}{l}\text { "...at least one time } \\
\text { per day" }\end{array}$ & $\begin{array}{l}\text { "... ao menos uma } \\
\text { vez por dia" }\end{array}$ & $\begin{array}{l}\text { Adequacy of the verb } \\
\text { tense }\end{array}$ \\
\hline BQ-Question 11f & $\begin{array}{l}\text { “...30 degraus de } \\
\text { escada por dia" }\end{array}$ & $\begin{array}{l}\text { “..30 rungs of stairs } \\
\text { a day" }\end{array}$ & $\begin{array}{l}\text { “..30 flights of stairs } \\
\text { a day" }\end{array}$ & $\begin{array}{l}\text { “...30 lances de } \\
\text { escada por dia” }\end{array}$ & Conceptual adequacy \\
\hline BQ-Question 39 & “... dor no joelho..." & “... wrist pain..." & “... knee pain...” & “... dor no joelho..." & Adequacy of word \\
\hline BQ-Questions 46, 47 & "... e no que o médico..." & $\begin{array}{l}\text { "... and not on what } \\
\text { the doctor..." }\end{array}$ & $\begin{array}{l}\text { "... and on what the } \\
\text { doctor..." }\end{array}$ & $\begin{array}{l}\text { "... e no que o } \\
\text { médico..." }\end{array}$ & Adequacy of meaning \\
\hline BQ-Question 50c & Nervoso & Irritable & Anxiety & Ansioso & Conceptual adequacy \\
\hline FQ-Question 24 c & Nervoso & Irritable & Anxiety & Ansioso & Conceptual adequacy \\
\hline
\end{tabular}

Figure 3 - Summary of adjustments made after further evaluation by the general coordinator in the Baseline Questionnaire (BQ) and in the Follow-up Questionnaire (FQ) 
The pre-final version of the CUPID questionnaire that was obtained in this stage was then tested in the pilot study.

\section{Pilot study results}

Nursing workers' profile

All 40 nursing workers who were selected for the pilot study agreed to take part. In this group, $40 \%$ were between 40 and 49 years of age, 25\% between 50 and 59 years, $22.5 \%$ between 30 and 39 years, and $10 \%$ between 20 and 29 years. Most (90\%) were women. Although there has been a substantial increase in the numbers of men entering the nursing profession, women still make up the large majority of nursing workers in Brazil.

As already described, $40 \%$ were nursing technicians, $32.5 \%$ nursing auxiliaries, and $27.5 \%$ nurses. Among nursing staff in the State of São Paulo as a whole, $20 \%$ are nurses, $17 \%$ nursing technicians, and $62 \%$ nursing auxiliaries(22). Data show that the study Hospital has a more highly trained nursing staff than other hospitals in the City of São Paulo and than in Brazil more widely.

With regard to other personal characteristics, $92 \%$ of participants were right-handed; $55 \%$ were white and $20 \%$ black; $72 \%$ had finished full time education by 16 years of age; $80 \%$ were between 151 and 170 centimeters tall; and $47 \%$ were smokers. Most of the nursing workers (95\%) had been working at the hospital for more than five years. In other words, they were experienced professionals who are likely to have been well adapted to the work process.

Current occupational activities

Some $72 \%$ of the nursing workers reported that, on a typical working day, they carried out repetitive movements of the wrists and fingers for more than four hours; $80 \%$ that their work involved repeated bending and straightening of the elbow for more than one hour in total; $50 \%$ that they lifted weights of $25 \mathrm{Kg}$ or more by hand; $37 \%$ that they knelt or squatted for more than an hour; and $60 \%$ that they worked under pressure to finish tasks. Most participants $(80 \%)$ reported that they made decisions, frequently or sometimes, about how to do their work and $50 \%$ about what to do in their work; $57 \%$ reported that they seldom or never made decisions about their timetable and breaks; the majority received help in their work when necessary, and reported satisfaction and feeling secure in their work.

\section{Symptoms}

Low back pain during the past 12 months was reported by $65 \%$ of participants. This compared with $9 \%$ for the neck, $50 \%$ for one or both shoulders, $25 \%$ for one or both elbows, $47 \%$ for one or both wrists, and $47 \%$ for one or both knees. In most cases, subjects reported that the pain persisted from one to four weeks, and needed consultation with a health professional. Despite the frequency of reported pain, absence from work was uncommon.

Other people's pain

Most participants reported that they knew others at work or outside work with back or arm pain.

\section{Completeness of answers}

The proportion of subjects who failed to answer a question satisfactorily ranged from $2 \%$ to $12 \%$. It was considered that this did not indicate a need to adjust the questionnaire.

\section{Conclusion}

The translated CUPID questionnaire is thus considered a satisfactory instrument for the ascertainment of occupational activities, psychosocial aspects of work, musculoskeletal symptoms and associated disability in Brazilian nursing workers.

As health professionals with at least intermediate levels of education, nursing workers are more familiar with the terminology used in the questionnaire than many other occupational groups, and this may facilitate their understanding of its content. Difficulties may arise with application of the instrument in other groups of workers, in which case it may better be administered through an interview than completed by self-administration. Also, the previous validity test of the questionnaire showed satisfactory results; however, other studies will be conducted, including other tests on the validity of this Brazilian version.

\section{References}

1. Alves D, Godoy SCB, Santana DM. Motivos de licenças médicas em um hospital de urgência-emergência. Rev Bras Enferm. 2006;59(2):195-200.
2. Ferrari AL. Adaptação transcultural do questionário Cultural Study of Músculo-skeletal and Other Symptoms and Associated Disability-CUPID Questionnaire. [dissertação]. São Paulo: Escola de Enfermagem/USP; 2009. 
3. Leite PC. A vivência de mulheres trabalhadoras de enfermagem que apresentam Distúrbios Osteomusculares Relacionados ao Trabalho (DORT): uma abordagem compreensiva da fenomenologia existencial. [tese]. São Paulo: Escola de Enfermagem/USP; 2006.

4. Felli VEA, Mininel VA, Sarquis LMM, Bernardino E . Surveillance of the health of nursing workers in Brazil. In: State-of-the-Art Conference/Internacional Conference on Occupacional Health for Health Care Workers (SOTAC/ICOH), 2007, Vancouver. Anais do State-of-the-Art Conference/Internacional Conference on Occupacional Health for Health Care Workers (SOTAC/ICOH). Vancouver - Canada: American College of Occupacional and Environmental Medicine; 2007. p. 4-5.

5. Ministério da Saúde (BR). Secretaria de Políticas de Saúde. Departamento de Ações Programáticas e Estratégicas. Área Técnica de Saúde do Trabalhador. Lesões por Esforços Repetitivos (LER) e Distúrbios Osteomusculares Relacionados ao Trabalho (DORT). Brasília; 2001. (Série A. Normas e Manuais Técnicos, 103).

6. Felli VEA, Tronchin DMR. A qualidade de vida no trabalho e a saúde do trabalhador. In: Kurcgant P. Gerenciamento em Enfermagem. Rio de Janeiro: Guanabara Koogan; 2005. p.75-88.

7. Alexandre NMC, Barros ENC. Cross-Cultural Adaptation of the Nordic Musculoskeletal Questionnaire. Int Nurs Rev. 2003;50(2):101-8.

8. Orfale AG. Tradução e Validação do Disabilities of the Arm, Shoulder and Hand (DASH) para a Língua Portuguesa. [Dissertação]. São Paulo: Escola Paulista de Medicina, Universidade Federal de São Paulo; 2003.

9. Vigatto R, Alexandre NMC, Correa HR Filho. Development of a Brazilian Portuguese Version of the Oswestry Disability Index: Cross-Cultural Adaptation, Reability and Validity. Spine. 2007;32(4):481-6.

10. Coggon D. Occupational medicine at a turning point. Occup Environ Med. 2005;62:281-3.

11. Madan I, Reading I, Palmer KT, Coggon D. Cultural differences in musculoskeletal symptoms and disability. Int J Epidemiol. 2008 Oct; 37(5):1189-91.

12. Solidaki E et al. Work-related and psychological determinants of multisite musculoskeletal pain. Scand J Work Environ Health. 2010 Jan;36(1):54-61.
13. Harcombe H, McBride D, Derret S, Gray A, Herbison P, Dean S. Musculoskeletal disorders and related disability in New Zealand nurses, postal and office workers. In: Conference "Opening doors: Celebrating Nursing Research", 2009, Wellington. Conference Handbook of the Conference Opening doors: Celebrating Nursing Research. Wellington - New Zealand: New Zealand Nursing Association; 2009. p.14.

14. Fabrício-Wehbe SCC, Schiaveto FV, Vendrusculo TRP, Haas VJ, Dantas RAS, Rodrigues RAP.Adaptação cultural e validade da Edmonton Frail Scale - EFS em uma amostra de idosos brasileiros. Rev. Latino-Am. Enfermagem. 2009 nov-dez;17(6):1043-9.

15. Hora EC, Sousa RMC. Adaptação transcultural do instrumento Family Needs Questionnaire Rev. Latino-Am. Enfermagem. 2009 jul-ago;17(4):541-7.

16. Novato TS, Grossi SAA, Kimura M. Adaptação cultural e validação da medida "Diabetes Quality of Life for Youths" de Ingersoll e Marrero para a cultura brasileira. Rev. Latino-Am. Enfermagem. 2008;16(2):224-30.

17. Toledo RCMR, Alexandre NMC, Rodrigues RCM. Avaliação das qualidades psicométricas de uma versão brasileira do spitzer quality of life index em pacientes com dor lombar. Rev. LatinoAm. Enfermagem. 2008;16(6):943-50.

18. Polit DF, Beck CT, Hungler BP. Fundamentos de pesquisa em enfermagem. 3. ed. Porto Alegre: Artes Médicas; 1995.

19. Beaton DC, Bombardier C, Guillemin F, Ferraz MB. Guidelines for the process of cross-cultural adaptation of self-report measures. Spine. 2000;25(24):3186-91.

20. LoBiondo-Wood G, Haber J. Confiabilidade e Validade. In: -. Pesquisa em enfermagem: métodos, avaliação crítica e utilização. Rio de Janeiro: Guanabara Koogan; 2001. p. 186-99.

21. Duarte PS, Miyazaki MCOS, Ciconelli RM, Sesso R. Tradução e adaptação cultural do instrumento de avaliação de qualidade de vida para pacientes renais crônicos (KDQOL-SFTM). Rev Assoc Med Bras[internet]. 2003; 49(4). [acesso 30 jun 2009]. Disponível em: http//:www.scielo.br/ scielo.php.

22. Conselho Regional de Enfermagem de São Paulo (CORENSP). Tabela de profissionais, autorizações e instituições organizada por cidade - período 12/2008. [internet]. São Paulo; 2009. [acesso 08 abr 2009]. Disponível em: http://corensp. or.br/072005/.

Received: Oct. $2^{\text {nd }} 2009$

Accepted: Jul. $23^{\text {th }} 2010$ 